\title{
FAKTOR- FAKTOR YANG BERHUBUNGAN DENGAN PENURUNAN NAFSU MAKAN PADA PASIEN GAGAL GINJAL KRONIK YANG MENJALANI TERAPI HEMODIALISIS (Studi Kasus Di Rsud Prof. Dr. Margono Soekarjo)
}

\author{
Factors Associated With Diminished Appetite in Chronic Kidney \\ Disease Patients Undergoing Hemodialysis Therapy (Case Study in \\ RSUD Prof. Dr. Margono Soekarjo)
}

\author{
Umi Faza Rokhmah ${ }^{1}$, Dyah Umiyarni Purnamasari ${ }^{1}$, Saryono ${ }^{2}$ \\ ${ }^{1}$ Program Studi Ilmu Gizi, Universitas Jenderal Soedirman, Jurusan Keperawatan, \\ Universitas Jenderal Soedirman \\ *alamat korespondensi : fazaumi@yahoo.com
}

\begin{abstract}
The aim of this study was to determine factors associated with diminished appetite in CKD patients undergoing hemodialysis therapy. This study is an observational analytic research with cross sectional design. Population of this study was CKD outpatients undergoing hemodialysis therapy in July-August 2016 in Prof. Dr. Margono Soekarjo Hospitals. Amount of 58 subjects taken by consecutive sampling. Appetite, sex, age, length of hemodialysis, frequency of nausea/vomiting, and depression were measured using questionnaire. Subjects who diminished appetite were 58,6\%. More than half subjects were male (56,9\%). Amount of $84,5 \%$ subjects were adults (19-59 years), $63,8 \%$ undergoing hemodialysis >1year, 39,7\% experienced nauseal vomiting and 53,4\% were depression. Based on Chi-Square Test/ Fisher Exact Test, diminished appetite significantly associated with length of hemodialysis $(p=0,041)$, frequency of nausea/vomiting $(p=0,014)$, and depression $(p=0,002)$. Dominant factors affected diminished appetite were depression and length of hemodialysis. Diminished appetite in CKD patients undergoing hemodialysis therapy associated with length of hemodialysis, frequency of nausea/vomit, and depression.
\end{abstract}

Keyword : appetite, chronic kidney disease, hemodialysi

\begin{abstract}
ABSTRAK
Penelitian ini bertujuan untuk mengetahui faktor- faktor yang berhubungan dengan penurunan nafsu makan pada pasien Gagal Ginjal Kronik (GGK) yang menjalani terapi hemodialisis. Penelitian ini merupakan penelitian analitik observasional dengan pendekatan cross sectional. Populasi dari penelitian ini adalah pasien GGK rawat jalan yang menjalani terapi hemodialisis pada bulan Juli- Agustus 2016 di RSUD Prof. Dr. Margono Soekarjo Purwokerto. Sebanyak 58 subjek diambil dengan cara consecutive sampling. Nafsu makan, jenis kelamin, usia, lama hemodialisis, frekuensi mual/muntah, dan depresi diukur menggunakan kuesioner. Responden yang mengalami penurunan nafsu makan sebanyak 58,6\%. Lebih dari separuh responden (56,9\%) berjenis kelamin laki- laki dan $84,5 \%$ responden berusia dewasa (19-59 tahun). Sebanyak 63,8\% responden menjalani hemodialisis $>1$ tahun. Responden yang mengalami mual/muntah berat sebanyak 39,7\% dan 53,4\% mengalami depresi. Berdasarkan analisis bivariat menggunakan Uji ChiSquare/ Fisher Exact diperoleh hasil bahwa nafsu makan berhubungan secara signifikan dengan lama hemodialisis $(p=0,041)$, frekuensi mual/ muntah $(\mathrm{p}=0,014)$, dan depresi $(\mathrm{p}=0,002)$. Faktor dominan yang mempengaruhi penurunan nafsu makan adalah depresi dan lama hemodialisis. Penurunan nafsu makan pada pasien GGK yang menjalani terapi hemodialisis berhubungan dengan lama hemodialisis, frekuensi mual/muntah, dan depresi.
\end{abstract}

Kata kunci : gagal ginjal, hemodialisa, nafsu makan 


\section{Pendahuluan}

Gagal ginjal kronik (GGK) merupakan perkembangan gagal ginjal yang bersifat progresif, lambat, dan biasanya berlangsung selama beberapa tahun. Ginjal kehilangan kemampuan untuk mempertahankan volume dan komposisi cairan tubuh dalam keadaan asupan normal (Price dan Wilson, 2006). Penyakit GGK ditandai Glomerular Filtration Rate (GFR) kurang dari 60 $\mathrm{mL} / \mathrm{menit} / 1,73 \mathrm{~m}^{2}$ dalam kurun waktu 3 bulan atau lebih (NKF-KDIGO, 2013). Menurut USRDS (2015), lebih dari $10 \%$ orang dewasa di Amerika Serikat mempunyai gagal ginjal kronik. Penderita GGK di Indonesia mengalami peningkatan $0,1 \%, 12 \%$ dari total penderita merupakan pasien baru GGK di Jawa Tengah (IRR, 2014). Berdasarkan data rekam medik RSUD Prof. DR Margono Soekarjo Purwokerto, jumlah pasien baru GGK yang menjalani hemodialisis pada tahun 2015 adalah 198 orang dengan total tindakan sebanyak 12.657 kali. Pada tahun 2016 tindakan hemodialisis mengalami peningkatan dari 1043 kali pada bulan Juli menjadi 1127 kali pada bulan Agustus.

Gagal ginjal terminal atau yang sering disebut sebagai End Stage Renal Disease (ESRD) membutuhkan terapi pengganti ginjal untuk dapat bertahan hidup (William dan Hopper, 2007). Hemodialisis merupakan salah satu terapi pengganti ginjal yang paling banyak digunakan. Pasien gagal ginjal kronik dengan hemodialis rentan mengalami kekurangan gizi. Syaiful et al. (2014) menyebutkan bahwa $49,15 \%$ pasien hemodialisis mengalami kekurangan gizi. Kekurangan gizi pada pasien hemodialisis disebabkan oleh beberapa faktor, diantaranya adalah peningkatan katabolisme protein, kehilangan zat gizi selama dialisis, inflamasi, komorbid, disfungsi hormonal, dan penurunan nafsu makan (Oliveira et al., 2015).

Penurunan nafsu makan berimplikasi pada rendahnya asupan makanan. Penelitian yang dilakukan oleh Wijayanti (2015) terhadap pasien gagal ginjal kronik yang menjalani terapi hemodialisis di RSUD Prof. Dr. Margono Soekarjo menunjukkan bahwa subjek yang tidak memenuhi standar asupan energi dan protein adalah sebesar $50 \%$ dan $82,1 \%$. Oleh sebab itu, lebih dari separuh $(60,71 \%)$. pasien GGK dengan 
penurunan nafsu makan memiliki resiko kematian dua kali lebih besar $(\mathrm{RR}=2,23)$ dibandingkan dengan pasien dengan nafsu makan baik (Lopes et al., 2007).

Penurunan nafsu makan pada pasien gagal ginjal kronik salah satunya berkaitan dengan tingginya kadar ureum akibat tidak memadainya terapi hemodialisis yang dilakukan. Kadar ureum yang tinggi dalam darah menimbulkan perasaan mual dan muntah (Gahong dan McPhee, 2010). Lopes et al. (2007) menyebutkan bahwa mual, karakteristik pasien (jenis kelamin dan usia), dan depresi berhubungan dengan penurunan nafsu makan. Hal ini sejalan dengan penelitian Bossola et al. (2012) yang menemukan bahwa nafsu makan kurang berhubungan dengan pasien yang berusia lebih tua dan mengalami depresi. Selain itu, penurunan nafsu makan juga berhubungan dengan lama pasien menjalani terapi hemodialisis (Carero et al., 2007).

Studi pendahuluan yang dilakukan pada pasien gagal ginjal kronik yang menjalani hemodialisis di RSUD Prof. DR Margono Soekarjo Purwokerto ditemukan bahwa 5 dari 7 pasien yang diwawancarai mengalami penurunan nafsu makan. Oleh karena itu, penelitian untuk mengetahui faktor- faktor yang berhubungan dengan penurunan nafsu makan pada pasien gagal ginjal kronik yang menjalani hemodialisis di RSUD Prof. Dr. Margono Soekarjo Purwokerto perlu dilakukan.

\section{Metode Penelitian}

Penelitian ini merupakan penelitian analitik observasional dengan pendekatan cross- sectional. Penelitian dilakukan di Instalasi Hemodialisis RSUD Prof. Dr. Margono Soekarjo Purwokerto pada bulan Juli- Agustus 2016. Sampel yang digunakan sebanyak 58 orang, diambil dengan cara concecutive sampling. Kriteria inklusi pada panelitian ini adalah pasien GGK rawat jalan $\geq 3$ bulan yang rutin menjalani terapi hemodialisis dengan frekuensi minimal 2 kali/ minggu, berjenis kelamin laki- laki atau perempuan, berusia $\geq 19$ tahun, compos mentis, mampu berkomunikasi dengan baik, dan bersedia menjadi responden. Responden dengan kegawatan, dementia, data tidak lengkap, mempunyai riwayat AIDS, kanker, 
Penyakit Paru Obstruksi Kronik (PPOK), dan sirosis hepatik dikeluarkan dari penelitian. Variabel nafsu makan, jenis kelamin, usia, lama hemodialisis, frekuensi mual/muntah, dan depresi diukur menggunakan kuesioner. Analisis bivariat yang digunakan adalah $\mathrm{Chi}$ Square/ Fisher Exact Test, sedangkan analisis regresi logistik ganda digunakan dalam analisis multivariat.

\section{Hasil dan Pembahasan}

Analisis univariat

Karakteristik responden berdasarkan jenis kelamin, usia, lama hemodialisis, frekuensi mual/muntah, dan depresi ditampilkan pada Tabel 1.

Tabel 1. Karakteristik Responden

\begin{tabular}{|c|c|c|c|c|}
\hline No & Variabel & & Jumlah & Persentase (\%) \\
\hline \multirow[t]{2}{*}{1.} & Nafsu makan & Baik & 24 & 41,4 \\
\hline & & Kurang & 34 & 58,6 \\
\hline \multirow[t]{2}{*}{2.} & Jenis kelamin & Laki- laki & 33 & 56,9 \\
\hline & & Perempuan & 25 & 43,1 \\
\hline \multirow[t]{2}{*}{3.} & Usia & Dewasa & 49 & 84,5 \\
\hline & & Lansia & 9 & 15,5 \\
\hline \multirow[t]{2}{*}{4.} & Lama Hemodialisis & $\leq 1$ tahun & 21 & 36,2 \\
\hline & & $>1$ tahun & 37 & 63,8 \\
\hline \multirow[t]{2}{*}{5.} & Frekuensi mual/muntah & Ringan & 35 & 60,3 \\
\hline & & Berat & 23 & 39,7 \\
\hline \multirow[t]{2}{*}{6.} & Depresi & Tidak Depresi & 27 & 46,6 \\
\hline & & Depresi & 31 & 53,4 \\
\hline
\end{tabular}

(Sumber : Data primer terolah, 2016)

\section{Sebanyak $58,6 \%$ responden} mengalami nafsu makan kurang. Penurunan nafsu makan yang terjadi pada pasien gagal ginjal kronik berkaitan dengan adanya retensi uremia, sitokin proinflamasi, gangguan hormonal dan neuropeptida (Carerro, 2009). Responden berjenis kelamin laki- laki (56,9\%) lebih banyak dibandingkan dengan perempuan $(43,1 \%)$. Menurut Goldberg dan Krause (2016) prevalensi gagal ginjal terminal lebih banyak terjadi pada laki- laki. Testosteron pada laki- laki dapat menginduksi terjadinya apoptosis podosit (yang berperan penting dalam terjadinya glomerulosklerosis) dan ekspresi TGF- $\beta 1$ (berhubungan dengan fibrosis jaringan). Sebaliknya, hormon seks pada perempuan seperti estrogen mempunyai efek protektif terhadap kerusakan ginjal. Responden yang berusia dewasa (19-59 tahun) lebih banyak dibandingkan responden lansia ( $\geq 60$ tahun) sebanyak 15,5\%. 
Rata- rata responden berusia 46,9 tahun. Setelah usia 40 ginjal akan mengalami penurunan laju filtrasi glomerulus secara progresif (Smeltzer dan Bare, 2010).

Responden dengan lama hemodialisis $>1$ tahun $(63,8 \%)$ lebih banyak dibandingkan dengan lama hemodialisis $\leq 1$ tahun $(36,2 \%)$. Pasien gagal ginjal kronik yang menjalani terapi hemodialisis memerlukan dialisis yang adekuat untuk menurunkan kadar produk ureum dalam darah. Keadaan ini akan terus berlangsung sepanjang hidup sehingga mempengaruhi kualitas hidup dan masa depan pasien hemodialisis (Chertow et al., 2006). Responden yang mengalami mual/muntah ringan lebih banyak $(60,3 \%)$ dibandingkan dengan mual/muntah berat $(39,7 \%)$. Mual/muntah merupakan gejala yang ditimbulkan akibat retensi toksin uremia dalam darah. Semakin banyak kadar ureum dalam darah semakin tinggi pula efek dalam menimbulkan mual/muntah (Smeltzer dan Bare, 2010). Responden yang mengalami depresi lebih banyak (53,4\%) dibandingkan dengan responden yang tidak mengalami depresi $(46,6 \%)$. Menurut Kimmel (2001) depresi pada pasien hemodialisis disebabkan oleh pembatasan diet dan cairan, komplikasi penyakit, kekhawatiran terhadap masa depan, kehilangan pekerjaan, ketergantungan terhadap terapi hemodialisis, serta keterbatasan dalam beraktifitas.

\section{Analisis bivariat}

Analisis bivariat antara jenis kelamin, usia, lama hemodialisis, frekuensi mual/muntah, dan depresi dengan nafsu makan ditampilkan pada Tabel 2.

Tabel 2. Hasil analisis bivariat antara jenis kelamin, usia, lama hemodialisis, frekuensi mual/muntah, dan depresi dengan nafsu makan responden

\begin{tabular}{|c|c|c|c|c|c|c|c|c|}
\hline & & \multicolumn{6}{|c|}{ Nafsu makan } & \multirow[t]{3}{*}{$\boldsymbol{P}$} \\
\hline & & \multicolumn{2}{|c|}{ Baik } & \multicolumn{2}{|c|}{ Kurang } & \multicolumn{2}{|c|}{ Total } & \\
\hline & & 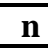 & $\%$ & $\mathbf{n}$ & $\%$ & $\mathrm{n}$ & $\%$ & \\
\hline \multirow[t]{2}{*}{ Jenis kelamin } & Laki- laki & 17 & 51,5 & 16 & 48,5 & 33 & 100 & 0,072 \\
\hline & Perempuan & 7 & 28,0 & 18 & 72,0 & 25 & 100 & \\
\hline \multirow[t]{2}{*}{ Usia } & Dewasa & 23 & 46,9 & 26 & 53,1 & 49 & 100 & 0,067 \\
\hline & Lansia & 1 & 11,1 & 8 & 88,9 & 9 & 100 & \\
\hline Lama & $\leq 1$ tahun & 5 & 23,8 & 16 & 76,2 & 21 & 100 & 0,041 \\
\hline hemodialisis & $>1$ tahun & 19 & 51,4 & 18 & 48,6 & 37 & 100 & \\
\hline \multirow{4}{*}{$\begin{array}{l}\text { Frekuensi } \\
\text { mual/muntah } \\
\text { Depresi }\end{array}$} & Ringan & 19 & 54,3 & 16 & 45,7 & 35 & 100 & 0,014 \\
\hline & Berat & 5 & 21,7 & 18 & 78,3 & 23 & 100 & \\
\hline & Tidak depresi & 17 & 63,0 & 10 & 37,0 & 27 & 100 & 0,002 \\
\hline & Kurang & 7 & 22,6 & 24 & 77,4 & 31 & 100 & \\
\hline
\end{tabular}

(Sumber : Data primer terolah, 2016) 
Hubungan Jenis Kelamin dan Nafsu Makan Responden

Berdasarkan uji statistik diperoleh hasil bahwa tidak ada hubungan antara jenis kelamin dan nafsu makan $(\mathrm{p}=0,072)$. Oliveira et al. (2015) juga memperoleh hasil serupa, yaitu tidak terdapat hubungan yang bermakna antara jenis kelamin dan nafsu makan $(\mathrm{p}=$ 0,9969). Responden yang mengalami penurunan nafsu makan lebih banyak ditemukan pada perempuan $(72 \%)$ dibandingkan laki- laki (48,5\%). Pada umumnya hormon seksual berperan dalam mempengaruhi perbedaan nafsu makan pada laki- laki dan perempuan. Hormon estradiol pada perempuan diketahui dapat menekan nafsu makan melalui pengaruhnya terhadap sistem saraf pusat. Sebaliknya, hormon testosteron mempunyai efek meningkatkan nafsu makan (Hischberg, 2012).

Tidak adanya hubungan antara jenis kelamin dan nafsu makan dikarenakan adanya pengaruh toksin ureum sehingga pengaruh hormon seksual terhadap nafsu makan tidak terlalu nyata. Retensi toksin ureum yang terdapat dalam tubuh ditandai dengan

adanya

mual/muntah.Frekuensi

mual/muntah berat tidak jauh berbeda antara responden laki- laki $(39,4 \%)$ dan perempuan (40\%). Selain itu, adanya retensi toksin ureum juga menimbulkan rasa metalik pada lidah. Oleh sebab itu, reponden merasakan tidak enak ketika makan (Proctor, 2005).

\section{Hubungan Usia dan Nafsu Makan}

\section{Responden}

Perhitungan secara statistik antara variabel usia dengan variabel nafsu makan menghasilkan nilai $\mathrm{p}$ sebesar 0,067, sehingga diartikan tidak ada hubungan yang bermakna antara keduanya. Penelitian Kalantar- Zadeh et al. (2004) juga memperoleh hasil yang sama yaitu tidak ada hubungan yang bermakna antara usia dan nafsu makan $(\mathrm{p}=0,3)$. Pada penelitian ini nafsu makan kurang lebih banyak dialami oleh responden pada kelompok lansia, yaitu sebanyak $(84,5 \%)$ dibandingkan dengan usia dewasa $(15,5 \%)$.

Penurunan nafsu makan pada lansia melibatkan perubahan rasa dan bau, cepatnya pemenuhan isi lambung, serta perubahan 
sensitifitas hormon adiposa dan gastrointestinal. Selama penuaan fungsi olfaktori mengalami penurunan sehingga berkurang sensasi rasa makanan. Hal ini mengakibatkan penurunan kenikmatan makan dan pemilihan variasi makanan. Kondisi cepat kenyang pada lansia disebabkan oleh kemampuan distensi lambung yang menurun. Penurunan distensi lambung menyebabkan lambung cepat terisi penuh sehingga sinyal kenyang menuju otak lebih cepat terjadi. Selain itu, sensitifitas terhadap hormon anoreksigenik seperti kolesistokinin (CCK) , Glukagon Like Peptide-1 (GLP-1), Polipeptida Y (PYY 3 -36), dan Oxyntomodulin (OXM) mengalami peningkatan (Britton dan McLaughlin, 2013). Tidak adanya hubungan bermakna antara usia dengan nafsu makan kurang dalam penelitian ini disebabkan oleh jumlah sampel lansia (8 orang) yang terlalu sedikit bila dibandingkan dengan usia dewasa (50 orang).

\section{Hubungan Lama Hemodialisis} dan Nafsu Makan Responden

$\begin{array}{ccr}\text { Hasil } & \text { uji } & \text { statistik } \\ \text { menunjukkan } & \text { bahwa } & \text { lama }\end{array}$

hemodialisis berhubungan dengan nafsu makan responden $(\mathrm{p}=0,041)$. Penelitian yang dilakukan oleh Carerro et al. (2007) juga menemukan hasil yang sama yaitu adanya hubungan yang bermakna antara lama hemodialisis dengan nafsu makan ( $\mathrm{p}<0,001)$. Pasien Gagal ginjal kronik yang menjalani hemodialisis dalam waktu lama memiliki kadar mediator proinflamasi seperti Tumor Nekrosis Factor Alpha (TNF- $\alpha$ ), C-Reactive Protein (CRP), dan interleukin yang tinggi dalam darah. Menurut Carerro (2009), tingginya kadar mediator proinflamasi dalam darah menyebabkan peningkatan peptida yang bersifat anoreksigenik seperti kolesistokinin, Glukosa LikePeptida 1 (GLP-1), dan PYY 3-36. Selain itu, pelepasan leptin (anoreksigenik) dari jaringan adiposa juga meningkat akibat stimulasi mediator proinflamasi (Caimi et al., 2005).

Hubungan Frekuensi Mual/Muntah dan Nafsu Makan

\section{Responden}

Berdasarkan analisis bivariat terdapat hubungan antara frekuensi mual/ muntah dengan nafsu makan 
responden $\quad(\mathrm{p}=0,014)$. Penelitian yang dilakukan Lopes et al. (2007) memperoleh hasil bahwa terdapat hubungan yang bermakna antara mual dengan penurunan nafsu makan $(\mathrm{p}<0,0001)$. Nafsu makan kurang lebih banyak terjadi pada responden yang mengalami mual/muntah berat $(78,3 \%)$ dibandingkan responden dengan mual muntah ringan $(45,7 \%)$.

Responden yang mengalami mengalami mual/muntah 4,27 kali lebih besar resikonya untuk mengalami nafsu makan kurang. Mual dan muntah menimbulkan perasaan yang tidak nyaman pada perut sehingga membuat seseorang menolak makanan atau tidak mampu menghabiskan sejumlah makanan yang disajikan (Lopes et al., 2007). Hirata et al. (2012) mengemukakan bahwa gangguan gastrointestinal seperti mual/ muntah pada pasien gagal ginjal kronik juga disebabkan oleh perlambatan pengosongan dan gangguan aktifitas mioelektrik pada lambung. Junior et al.(2013) menemukan bahwa pasien dengan gejala mual/muntah memiliki waktu pengosongan lambung (238 menit) lebih lama dibandingkan dengan pasien tanpa gejala mual dan muntah (185,5 menit).

\section{Hubungan Depresi dan Nafsu Makan Responden}

Berdasarkan analisis bivariat, didapatkan hasil bahwa terdapat hubungan yang bermakna antara depresi dengan nafsu makan kurang responden $(\mathrm{p}=0,002)$. Hal ini sejalan dengan penelitian Lopes et al. (2007) yang menemukan bahwa ada hubungan bermakna antara depresi dan nafsu makan kurang pada pasien gagal ginjal kronik dengan hemodialisis $\quad(p<0,0001) . \quad$ Nafsu makan kurang lebih banyak terjadi pada responden yang mengalami depresi $(77,4 \%)$ dibandingkan responden yang tidak mengami depresi (37\%). Hilangnya nafsu makan akibat depresi menyebabkan perubahan fisiologis yang mirip dengan cepatnya rasa kenyang (Kuijer dan Boyce, 2012).

Depresi juga dapat mempengaruhi fungsi saluran gastrointestinal. Penelitian yang dilakukan oleh Sang Pyo, et al. (2015) menemukan bahwa responden dengan depresi $66,6 \%$ lebih beresiko mengalami dispepsia 
fungsional dibandingkan dengan responden tanpa depresi. Hal ini berkaitan dengan perubahan sekresi lambung akibat gangguan jalur endokrin melalui HipotalamusPituitary-Adrenal Axis (HPA Axis). Peningkatan asam lambung menimbulkan gejala seperti nyeri, mual, dan perasaan cepat kenyang sehingga berakibat pada turunnya nafsu makan (Junior et al., 2013). Depresi dapat meningkatkan kadar sitokin proinflamasi di dalam tubuh. Kadar IL-6 pada pasien hemodialisis yang mengalami depresi lebih tinggi $(8 \pm 1,55 \quad \mathrm{pg} / \mathrm{ml}) \quad$ dibandingkan dengan pasien tanpa depresi $(6,89 \pm 1,65 \mathrm{pg} / \mathrm{ml})$ (Hung et al., 2011). Adanya sitokin proinflamasi menghambat nafsu makan melalui pengaruh sinyal peripheral dan pusat (Carerro, 2009).

\section{Analisis Multivariat}

yang mempunyai $\mathrm{p}<0,25$ pada analisis bivariat (Dahlan, 2011). Hasil analisis multivariat pada penelitian ini ditampilkan pada Tabel 3.

Berdasarkan analisis multivariat, depresi dan lama hemodialisis merupakan faktor dominan yang mempengaruhi nafsu makan responden. Responden dengan depresi 8,87 kali berpotensi mengalami nafsu makan kurang dibandingkan dengan reponden yang tidak mengalami depresi. Pengaruh yang besar dari depresi terhadap penurunan nafsu makan tidak hanya berkaitan dengan kondisi psikologis tetapi juga kondisi biologis. Selain itu, beberapa hal juga dapat mempengaruhi terjadinya depresi seperti jenis kelamin, usia, dan komplikasi penyakit.

Tabel 3. Hasil analisis multivariat

\begin{tabular}{lcccc}
\hline Variabel & B & Sig & OR & 95\% CI \\
\hline Lama hemodialisis & 1,776 & 0,015 & 1,69 & $0,040-0,711$ \\
Depresi & 2,183 & 0,001 & 8,870 & $2,337-33,663$ \\
\hline
\end{tabular}

Analisis multivariat menggunakan analisis regresi logistik ganda dengan metode Backward Stepwise. Variabel yang dimasukkan dalam analisis multivariat merupakan variabel
Perasaan sedih dan putus asa akibat depresi mengakibatkan hilangnya hasrat untuk mengonsumsi makanan. Perasaan sedih dan putus asa berkaitan dengan tipe kepribadian pasien. 
Penelitian yang dilakukan Afifah dan Wardhana (2015) menemukan bahwa tipe kepribadian introvert lebih beresiko mengalami gangguan makan dari pada tipe kepribadian extrovet $\quad(p=0,017)$ Hal ini disebabkan individu dengan tipe kepribadian introvert cenderung mengembangkan emosi negatif seperti gejala ketakutan, merasa rendah diri, kaku dan menunjukkan intrapersonal variability yang kecil. Adanya pembatasan diet dan cairan juga membuat nafsu makan pasien semakin menurun (Gerogianni, 2003). Hung et al. (2011) mengungkapkan bahwa pasien depresi memiliki kadar serum albumin lebih rendah $(37 \pm 3 \mathrm{~g} / \mathrm{L})$ dibandingkan dengan pasien yang tidak mengalami depresi $(39 \pm 4$ g/L).Rendahnya kadar serum albumin menandakan buruknya asupan makanan akibat penurunan nafsu makan.

Faktor dominan selanjutnya yang mempengaruhi nafsu makan adalah lama hemodialisis. Pasien yang menjalani hemodialisis lebih lama akan cenderung mengalami penurunan nafsu makan yang menetap akibat penumpukan sitokin proinflamasi. Tingginya sitokin proinflamasi disebabkan oleh kerusakan ginjal maupun akibat penyakit komplikasi yang menyertai (Zabel,2009). Lama hemodialisis berkaitan pula dengan munculnya depresi. Menurut Gerogianni dan Babatsikou (2014), semakin lama seseorang menjalani hemodialisis maka semakin tinggi pula resiko terjadinya depresi. Depresi lebih banyak dialami oleh responden dengan lama hemodialisis $>1$ tahun (56,8\%) dibandingkan dengan responden dengan lama hemodialisis $\leq 1$ tahun $(47,6 \%)$.

Frekuensi mual/muntah tidak memberikan pengaruh dominan terhadap penurunan nafsu makan responden. Hal ini dikarenakan mual/muntah yang dialami reponden termasuk kategori ringan. Berdasarkan hasil pengukuran, responden yang mengalami mual/muntah ringan lebih banyak $(60,3 \%)$ dibandingkan dengan responden yang mengalami mual/muntah berat $(39,7 \%)$.

\section{Kesimpulan Dan Saran}

Sebagian besar responden mengalami nafsu makan kurang 
ISSN 2599-0152 eISSN 2599-2465

http://jos.unsoed.ac.id/index.php/jgps

$(58,6 \%)$, berjenis kelamin laki- laki $(56,9 \%)$, berusia dewasa $(84,5 \%)$, menjalani hemodialisis $>1$ tahun (63,8\%), mempunyai mual/muntah ringan $(60,3 \%)$, dan mengalami depresi $(53,4 \%)$. Penurunan nafsu makan pasien gagal ginjak kronik yang menjalani hemodialis di RSUD Prof. Dr. Margono Soekarjo berhubungan dengan lama hemodialisis, frekuensi mual/muntah, dan depresi. Faktor yang dominan berpengaruh terhadap penurunan nafsu makan adalah depresi dan lama hemodialisis. Pihak rumah sakit diharapkan dapat memberikan konseling gizi yang rutin untuk memotivasi pasien tetap mempertahankan asupan makanan sesuai diet yang diberikan. Pasien harus tetap menjaga asupan makanan sesuai dengan preskripsi diet yang diberikan. Mengonsumsi makanan dengan porsi kecil tapi sering, memilih makanan yang disukai, menciptakan suasana makan yang sesuai dapat menjaga asupan makanan pasien. Selain itu, diharapkan kepada keluarga pasien untuk senantiasa mengingatkan dan memotivasi pasien untuk tetap makan meskipun pasien sedang mengalami penurunan nafsu makan.

\section{Daftar Pustaka}

Afifah, L. M. dan Wardhana, I.S.P. 2015. Pengaruh Tipe Kepribadian ExtrovertIntrovert terhadap Emotional Eating pada Wanita Dewasa Awal. Jurnal Psikologi Klinis dan Kesehatan Mental. 4 (3): 198-205.

Bossola, M., Ciciarelli, C., DiStasio, E., Panocchia N., Conte, G.L., Rosa F., Tortorelli, A., Luciani G., dan Tazza L. 2012. Relationship Between Appetite and Symptomps of Depression and Anxiety in Patients on Cronic Haemodialysis. Journal of Renal Nutrition. 22 (1): 27-33.

Britton, E. dan McLaughlin, JT. 2013. Ageing and The Gut, Conference on Nutrition Society Symposium. Proceedings International Seminar "Malnutrition matters" Nutrition Society, England. 173-177.

Carrero, J.J. 2009. Identification of Patients with Eating Disorders: Clinical and Biochemical Signs of Appetite Loss in Dialysisi Patients, Journal of Renal Nutrition, 19(1) : 10-15

Chertow, G.M., Johansen,K.L., Lew, N., Lazarus, M., dan Lowrie, E.G. 2000. Vintage, Nutritional Status, and Survival in Hemodialysis Patients. Kidney International, 57 (1) : 11761181

Dahlan, S. 2011. Statistik Untuk Kedokteran dan Kesehatan Edisi 5. Salemba Medika. Jakarta : 115- 121.

Gahong, W.F. dan McPhee, S.J. 2010. 
ISSN 2599-0152 eISSN 2599-2465 http://jos.unsoed.ac.id/index.php/jgps

Patofisiologi Penyakit : Pengantar Menuju Kedokteran Klinis, Edisi 5, Alih Bahasa: dr. Brahm U. Pendit. EGC. Yogyakarta : 506-602.

Gerogianni, K.G. 2003. Stressor of Patients Undergoing Chronic Hemodialysis, Nursing. 42 (2) : 228-246.

Gerogianni, S.K. dan Babatsikou, F.P. 2014. Psychological Aspects in Chronic Renal Failure. Health Science Journal. 8 (2) : 205-214

Goldberg, I. Dan Krause, I. 2016. The Role of Gender in Chronic Kidney Disease. European Medical Journal. 1 (2) : 5864.

Hischberg, A.L. 2012. Sex Hormones, Appetite, and Eating Behavior in Women. Journal of Maturitas. 71 (3) : 248-256.

Hung, K.C., Wu, C.C., Chen, H.S., Ma, W.Y., Tseng, C.F., Yang, L.K., Hsieh, H.L., dan Lu, K.C.. 2011. Serum IL-6, Albumin and Comorbidities are Closely Correlated with Symptoms of Depression in Patients on Maintenance Haemodialysis. Nephrol Dial Transplant, 26 (1) : 658-664.

Indonesian Renal Registry (IRR). 2014. $7^{\text {th }}$ Report Of Indonesian Renal Registry, Indonesian Renal Registry, Jakarta.

Junior, L.D.S., Santos, P.R., Santos A.A.D, Souza, M.H.L.P.D. 2013. Dyspepsia and Gastric Emptying in End Stage Renal Disease Patients on Hemodialysis, Biomed Central Nephrology. 14 (1) : 275-280.

Kalantar- Zadeh, K., Block, G.J., Mc, A.C., Humphreys, M.H., Kopple, J.D. 2004.
Appetite and Inflammation, Nutrition, Anemia, and Clinical Outcome in Haemodialysis Patients, American Journal of Clinical Nutrition. 80 (1) : 299-307.

Kimmel, P.L. 2001. Psychological Factors in Dialysis Patients, Kidney International Journal. 59 (1) : 15991613.

Kuijer, R. G. dan Boyce, J.A. 2012. Emotional Eating and Its Effect in Eating Behavior After a Natural Disaster. Appetite. 58 (3) : 936 - 939.

Lopes, A.A., Elder, S.J., Ginsberg, N., Andreucci, V.E., Cruz, J.M., Fukuhara, S., Mapes, D.L., Saito, A., Pisoni, R.L., Saran, R., dan Port, F.K.,. 2007. Lack of Appetite in Haemodialysis Patients- Associations with Patient Characteristics, Indicators of Nutritional Status and Outcomes in The International DOPPS. Nephrol Dial Transplant. 22 (12) : 3538 -3546.

NKF-KDIGO. 2013. Clinical Practice Guideline for the Evaluation and Management of Chronic Kidney Disease. Journal of the International Society of Nephrology. 3 (1) : 259 303.

Oliveira, C.M.C., Kubrusly, M., Lima, A.T., Torres, D.M., Cavalvante, N.M.R., Jeronimo, A.L.C., Oliveira, T.C.B. 2015. Correlation Between Nutritional Markers and Appetite SelfAssessments in Hemodialysis Patients. Journal of Renal Nutrition. 25 (3) : 301-307.

Price S. A. dan Wilson L. M. 2006. 
ISSN 2599-0152 eISSN 2599-2465

http://jos.unsoed.ac.id/index.php/jgps

Patofisiologi: Konsep Klinis Proses-Proses

Penyakit, Edisi 6 volume 2, Alih Bahasa,

Brahm U. Pendit, Penerbit Buku

Kedokteran EGC, Jakarta : 912-918.

Proctor, Kumar, N., Stein, A., Males, D., Porter, A. 2005. Oral and Dental Aspects of Chronic Renal Failure. Journal of Dental Research. 84 (3) : 199-207

Sang Pyo, L., In-Kyung, S., Jeong Hwan, K., Sun-Young, L., Hyung Seok, P., and Chan Sup S. 2015. The Effect of Emotional Stress and Depression on the Prevalence of Digestive Diseases, Journal Neurogastroenterol Motil, 21 (2) : 273-282.

Smeltzer, S.C. dan Bare, B.G. 2010. Brunner \& Suddarth Textbook of Medical-Surgical Nursing Volume 1, Lippincott Williams \& Wilkins, 11121116.

Syaiful, H.Q., Oenzil F., dan Afriant, R. 2014. Hubungan Umur dan Lamanya Hemodialisis dengan Status Gizi pada Penderita Penyakit Gagal Ginjal Kronik yang Menjalani Haemodialisis di RS. Dr. Djamil Padang. Jurnal Kesehatan Andalas. 3 (3) : 271-277

United State Renal Data System (USRDS).

2015. CKD in The United State, United States Renal Data System. 1 (1) : 13-24. Wijayanti, T.S. 2015. Hubungan Asupan Energi dan Protein dengan Status Gizi Pasien Gagal Ginjal Kronik yang Menjalani Haemodialisis. Skripsi.

Universitas Jenderal Soedirman, Purwokerto.

William, L.S. dan Hopper, P.D. 2007.
Understanding Medical Surgical Nursing, $3^{\text {th }} E d$., F.A. Davis Company, USA : 796-801.

Zabel, R. 2009. New Insight into Appetite, Inflammation and Use of Fish Oil in Hemodialysis Patients, Thesis, Queensland University of Technology, Australia. 